\title{
Concentration of pineapple juice by reverse osmosis: physicochemical characteristics and consumer acceptance
}

\author{
Concentração de suco de abacaxi por osmose inversa: características físico-químicas e aceitação do consumidor
}

\author{
Daniel Simões COUTO ${ }^{1 *}$, Lourdes Maria Corrêa CABRAL², Virgínia Martins DA MATTA², \\ Rosires DELIZA³ ${ }^{3}$ Daniela de Grandi Castro FREITAS²
}

\begin{abstract}
Reverse osmosis has been used for the concentration of fruit juices with promising considering the quality of the obtained products. The objective of this study was to concentrate single strength pineapple juice by reverse osmosis. The concentration was carried out with polyamide composite membranes in a $0.65 \mathrm{~m}^{2}$ plate and frame module at $60 \mathrm{bar}$ transmembrane pressure at $20^{\circ} \mathrm{C}$. The permeate flux was $17 \mathrm{~L} . \mathrm{hm}{ }^{-2}$. The total soluble solid content of the juice increased from 11 to $31^{\circ}$ Brix corresponding to a Volumetric Concentration Factor (VCF) of 2.9. The concentration of soluble solids, total solids, and total acidity increased proportionally to FCV. The concentrated juice and three commercial concentrated pineapple juices were evaluated regarding preference and purchase intention by 79 pineapple juice consumers. The concentrated juice by reverse osmosis was the preferred among consumers. It can be concluded that this process may be considered an alternative to the pre-concentration of fruit juices.
\end{abstract}

Keywords: cold concentration; fruit juice; preference; consumers.

\section{Resumo}

A osmose inversa tem sido utilizada para a concentração de sucos de frutas com resultados promissores em relação à qualidade dos produtos obtidos. Este trabalho teve como objetivo a concentração de suco de abacaxi por osmose inversa. A concentração foi conduzida com membranas de poliamida em um módulo de configuração quadro e placas com área total de permeação de $0,65 \mathrm{~m}^{2}$ a 60 bar de pressão aplicada à membrana. O fluxo de permeado foi de $17 \mathrm{~L} \cdot \mathrm{hm}^{-2}$. O teor de sólidos solúveis do suco aumentou de 11 para $31^{\circ} \mathrm{Brix}$, correspondendo ao Fator de Redução Volumétrica (FRV) de 2.9. A concentração do teor de sólidos totais e acidez aumentaram proporcionalmente ao fator de redução volumétrica. O suco concentrado e três marcas de suco de abacaxi concentrado foram avaliados em relação à preferência e intenção de compra por 79 consumidores de suco de abacaxi. O suco concentrado por osmose inversa foi o preferido entre os consumidores. Pode-se concluir que este processo pode ser considerado como uma alternativa na concentração de sucos de frutas.

Palavras-chave: concentração a frio; suco de fruta; preferência; consumidores.

\section{Introduction}

Pineapple is one of the most popular tropical non-citrus fruit, mainly because of its attractive aroma, refreshing flavour, and its balance between acidity and sweetness (BARTOLOMÉ; RUPÉREZ; FÚSTER, 1995). Its juice has been used in based fruit beverages individually, in the form of mixture, or combined with other fruit juices. As an ingredient, the concentrated pineapple juice blends well with other aromas of fruits resulting in a pleasant product with a competitive market price available to consumers of all ages. It stands out because of its energetic value on account of its high composition of sugars and nutritional value due to the presence of mineral salts - calcium, phosphorous, magnesium, potassium, sodium, copper, and iodine - and vitamins - C, A, B1, B2, and niacin. Nonetheless, it presents protein and fat content lower than $0.5 \%$ (CABRAL; FREIRE JUNIOR; MATTA, 2005).

Epidemiologic studies suggest that the antioxidant activity of fruits is beneficial to cardiovascular diseases (VINSON et al., 2001) by avoiding the aggregation of plaques in the blood vessels (HOLLMAN; HERTOG; KATAN, 1996) and reducing the incidence of cerebral vascular accidents (JOSHIPURA et al., 1999). Fruits exhibit antioxidant capacity due to phenolic compounds, which may benefit the Low Density Lipoproteins (LDL) protecting them from oxidation. A serving of $78 \mathrm{~g}$ of fresh pineapple is equal to $52 \mathrm{mg}$ of phenolic compounds (expressed as catechin equivalent), according to a study conducted by Vinson et al. (2001).

\footnotetext{
Received $2 / 2 / 2010$

Accepted 4/11/2010 (004654)

${ }^{1}$ Departamento de Tecnologia de Alimentos, Universidade Federal Rural do Rio de Janeiro - UFRRJ, Rod. BR 465, Km 7, CEP 23890-000, Seropédica, RJ, Brazil, e-mail:daniel.alimentos@gmail.com

2 Agroindústria de Alimentos, Av. das Américas, 29501, CEP 23020-470, Guaratiba, Rio de Janeiro, RJ, Brasil

${ }^{3}$ Embrapa Labex Europa, Inra, UMR CSGA, 21000, Dijon, France

${ }^{*}$ Corresponding author
} 
Pineapple juice is widely commercialized as concentrated juice. Vacuum evaporation stands out as the most used procedure by the industries of concentrated juices. The main advantages of evaporation are the capacity to reach high concentrations, the versatility of concentrating different products, and to allow other procedures to be performed simultaneously (FELLOWS, 2006). One disadvantage is that it presents the degradation of composites sensitive to heat, as well the loss of volatile substances, reactions of browning, enzymatic darkening, coagulation, flocculation, and precipitation, besides being an energy-consuming process (ÁLVAREZ et al., 2000; GIRARD; FUKUMOTO, 2000).

Reverse osmosis, a membrane concentration process, has been pointed out as an alternative technique to thermal concentration. It can be used to concentrate fruit juices at room temperature without any changes in the physical structure of water, hence minimizing the damages caused by the utilization of heat. In addition, the costs of processing and energy are lower, and high quality products are obtained due to the maintenance of the aroma and flavour compounds and those responsible for nutritional characteristics (MULDER, 1991).

In this process, dense membranes with good mechanic resistance have to be used since this process demands the application of high transmembrane pressures in order to overlap the high osmotic pressure of the fruit juices (MULDER, 1991). Depending on the type of the fruit, it is possible to concentrate juices by reverse osmosis up to a total soluble solid content of $35^{\circ}$ Brix (ÁLVAREZ et al., 2000; SÁ; CABRAL; MATTA, 2003; JESUS et al., 2007).

Therefore, the objective of this study was to evaluate the quality of the pineapple juice concentrated by the reverse osmosis process.

\section{Materials and methods}

As raw material, it was utilized the Smooth Cayenne pineapple cultivar from two different batches: one for the experimental design and the other for the concentration process. Both specimens were from the same lot of fruits and were in green to ripe maturation stage. The single strength pineapple juice was obtained from the fruit pulping in a finisher with a $0.6 \mathrm{~mm}$ sieve. The juice was centrifuged in a basket centrifuge at $4,000 \mathrm{rpm}(2.529 \mathrm{G})$. The study was conducted using the same lot of the pineapple juice stored at $-18{ }^{\circ} \mathrm{C}$.

Reverse osmosis experiments were conducted in a plate and frame module (LAB UNIT M20 - DSS, Denmark) with a permeation area of $0.65 \mathrm{~m}^{2}$ using composite membranes of polyamide (HR98PP, 98\% rejection to sodium chloride).

The juice permeability was determined through the measurement of permeate flux, in the stationary stage, with the recirculation of the chains of permeate and retentate, constant temperature, and with different pressures applied to the membrane.

\subsection{Experimental design}

A complete $2^{2}$ factorial design with triplicate of the central point was performed totalizing seven assays with the objective of evaluating the influence of the transmembrane pressure and temperature of the process (independent variables) on the physicochemical characteristics and consumer acceptance of the final product (dependent variables).

The processes were conducted in a stationary state, where the permeate and the retentate returned to the feed tank, without the juice concentration, for a period of two hours, an average that is used in the concentration by reverse osmosis process. The transmembrane pressures utilized were 20, 40, and $60 \mathrm{bar}$, and the temperatures were 20,30 , and $40{ }^{\circ} \mathrm{C}$. The permeate flux was assessed at every 15 minutes in triplicate.

\subsection{Reverse osmosis concentration process}

The concentration process was conducted under the transmembrane pressure and temperature conditions previously defined by the analysis of the data of the experimental design. The concentration was conducted in a batch feed mode, i.e., with addition of $1 \mathrm{~L}$ juice at every litter of permeate collected, totalizing $25 \mathrm{~L}$ of juice. The permeate flux and the soluble solid content were measured every 15 minutes. The process was performed in triplicate.

\subsection{Analytical methods}

The samples of the pineapple juices under different process conditions were analyzed regarding the following physical and chemical parameters: $\mathrm{pH}$ in Metronal E120 potentiometer; total titrated acidity through the titration with sodium hydroxide and phenolphthalein as indicator (ASSOCIATION..., 2005 942.15); soluble solids content through the direct reading in Bellingham + Stanley Limited refractometer with a ${ }^{\circ}$ Brix scale to $20^{\circ} \mathrm{C}$ (ASSOCIATION..., 2005 - 932.14); and total solids content, by the determination of the dry weight in a vacuum oven (ASSOCIATION..., 2005 -934.01).

The total phenolic content analysis was determined using a BIOSPECTRO-SP 220 spectrophotometer at $760 \mathrm{~nm}$. Initially, an extraction with acetone-water mixture at $70 \%$ was carried out. Folin-Ciocalteu reagent $10 \%$ and sodium carbonate $7.5 \%$ were used in the colorimetric reaction. The result was expressed as Gallic acid equivalent, as described by Singleton and Rossi (1965).

The instrumental colour analysis was performed with the transmittance mode in the colorimeter S\&M Colour Computer, SM-4-CH model (Suga, Japan), in the Hunter system with an overture of $30 \mathrm{~mm}$ diameter $(\mathbf{L}=$ luminosity $(0=$ black and $100=$ white $) ; \mathbf{a}(-80$ to zero $=$ green, from zero to $+100=$ red $) ;$ and $\mathbf{b}(-100$ to zero $=$ blue, from zero to $+70=$ yellow $)$. Four assays were performed on a petri plate $(0.5 \mathrm{~cm}$ diameter and $2 \mathrm{~cm}$ height). Haze was determined by the relationship between the diffuse relative transmission and total transmission.

The analyses of minerals were performed by the ash mineralization method (ASSOCIATION..., 2005 - 999.11) and quantification using Inductively Coupled Plasma (ICP) (ASSOCIATION..., 2005 - 990.08). 


\subsection{Sensory evaluation}

Consumer evaluation was conducted with individuals (males and females) who liked pineapple juice. The tests were carried out at Embrapa Food Technology, Sensory and Instrumental Evaluation Laboratory, Rio de Janeiro, RJ, Brazil.

The seven juice samples related to the seven assays of the experimental planning were evaluated with the aim of determining the best process conditions according to the consumer perception, and the analysis was performed using the Preference Test and Purchase intention with 84 pineapple juice consumers. The ideal sugar content of the juices was previously determined by 80 consumers through the "ideal sweetness" test (3.59 g.100 mL $\mathrm{mL}^{-1}$ ) (DELIZA, 2001). The samples were presented monadically following a balanced presentation order, according to MacFie et al. (1989), at $8 \pm 1{ }^{\circ} \mathrm{C}$ in individual sensory booths.

The "ideal" sweetness level was estimated by regressing data and the estimated value used to prepare the samples obtained from the pineapple juice concentration process.

After the concentration process, the Preference Test and Purchase intention were carried out with 79 pineapple juice consumers of both sexes. Consumers' preference was evaluated using a 9-point hedonic scale according to the method described by Meilgaard, Civille and Carr (1991), varying from: 1 - "I extremely disliked it" to 9 - "I extremely liked it". Intention to Purchase was investigated by means of a 7-point structured scale varying from 1 - "I would not definitely buy it" to 7 - "I would definitely buy it". Four samples were presented to consumers: one sample of concentrated juice by reverse osmosis and three samples of commercial brands of concentrated pineapple juice reconstituted and sweetened with commercial sugar (sucrose). The dilution level of the juices was previously determined with 80 consumers through the test of the "ideal dilution" (10.38 ${ }^{\circ}$ Brix) before being sweetened at $3.59 \mathrm{~g} .100 \mathrm{~mL}^{-1}$. The samples were monadically presented in disposable plastic cups codified with three-digit numbers and served at refrigeration temperature $\left(8 \pm 1^{\circ} \mathrm{C}\right)$ in individual sensory booths. The order of the presentation of the samples was balanced according to MacFie et al. (1989).

Before each sensory test, consumers received and signed a Consent Form in which the objectives of the study were explained. They were also told that they could leave the session at any time without any explanation and could contact the responsible for the study to get any further information. The research protocol was submitted and approved by the Brazilian CEP (Ethics on Research Committee, CAAE - 0013.0.309.000-08).

\subsection{Statistical data analysis}

Data of the experimental design were analysed using the Statistica 7.0 software. Data of the preference and those of the relative to ideal tests were analyzed through the analysis of variance (ANOVA) and test of means using the statistical XLSTAT 7.5 software (1995). The results of the instrumental and physicochemical analyses were treated using the statistical XLSTAT 7.5 software (1995).

\section{Results and discussion}

It can be observed that the relationship between transmembrane pressure and permeate flux was linear for all the range of the evaluated pressure indicating that the limit of the flux was not reached. It was verified, as expected, an increase in the permeate flux with the increase of temperature and pressure, as well a decrease in permeability when comparing water and juice processes in the same conditions (Figure 1).

The highest permeate flux was obtained at $40^{\circ} \mathrm{C}$ and $60 \mathrm{bar}$, and the lowest fluxes were verified in the processes conducted at 20 bar. The processes conducted at 40 bar and $30{ }^{\circ} \mathrm{C}$ presented similar flux of the process conducted at $60 \mathrm{bar}$ and $20^{\circ} \mathrm{C}$, hence emphasizing the effect of temperature and pressure on the permeate flux (Figure 2).

Considering only the permeate flux, the best process condition would be that of the highest temperature and transmembrane pressure $\left(40^{\circ} \mathrm{C}\right.$ and 60 bar $)$.

In order to confirm this condition, the samples of pineapple juice at the beginning and after two hours of the process were evaluated regarding their physicochemical (Table 1) and sensory characteristics. No significant differences were found $(\mathrm{p}<0.05)$ among the samples processed in the different pressures and temperatures concerning the physicochemical characteristics.

Nonetheless, in the preference test, it was observed a difference among the seven samples of the experimental planning, and the process conducted at 60 bar and $20^{\circ} \mathrm{C}$ was the preferred among consumers $(\mathrm{p}<0.05)$.

This condition was then selected for the performance of the pineapple juice concentration through reverse osmosis.

The concentration process presented an initial flux of $17 \mathrm{~L}$. $\mathrm{hm}^{-2}$ and a median flux of $9.3 \mathrm{~L} \cdot \mathrm{hm}^{-2}$. A decrease in the permeate flux along the process was observed; a phenomenon which may be explained by the accumulation of material in the membrane surface (polarization of the concentration and fouling), the

Table 1. Results of the analyses of the processes in stationary stage.

\begin{tabular}{|c|c|c|c|c|c|c|c|}
\hline & \multicolumn{2}{|c|}{20 bar } & \multicolumn{2}{|c|}{60 bar } & \multicolumn{3}{|c|}{40 bar } \\
\hline & $20^{\circ} \mathrm{C}$ & $40^{\circ} \mathrm{C}$ & $20^{\circ} \mathrm{C}$ & $40^{\circ} \mathrm{C}$ & $30^{\circ} \mathrm{C}$ & $30^{\circ} \mathrm{C}$ & $30^{\circ} \mathrm{C}$ \\
\hline $\mathrm{pH}$ & $3.46^{\mathrm{a}} \pm 0.01$ & $3.46^{\mathrm{a}} \pm 0.01$ & $3.45^{\mathrm{a}} \pm 0.01$ & $3.46^{\mathrm{a}} \pm 0.01$ & $3.44^{\mathrm{a}} \pm 0.01$ & $3.46^{\mathrm{a}} \pm 0.01$ & $3.45^{\mathrm{a}} \pm 0.01$ \\
\hline Acidity (mg.100 g $\mathrm{g}^{-1}$ of Citric acid) & $0.68^{\mathrm{a}} \pm 0$ & $0.72^{\mathrm{a}} \pm 0.07$ & $0.75^{\mathrm{a}} \pm 0.06$ & $0.72^{\mathrm{a}} \pm 0.03$ & $0.66^{\mathrm{a}} \pm 0$ & $0.75^{\mathrm{a}} \pm 0.04$ & $0.66^{\mathrm{a}} \pm 0.04$ \\
\hline Content of soluble solids ( $\left.{ }^{\circ} \mathrm{Brix}\right)$ & $12.3^{\mathrm{a}} \pm 0$ & $12^{\mathrm{a}} \pm 0$ & $12.6^{\mathrm{a}} \pm 0.06$ & $12.4^{\mathrm{a}} \pm 0.06$ & $11.9^{\mathrm{a}} \pm 0.06$ & $12.6^{\mathrm{a}} \pm 0.06$ & $11.6^{\mathrm{a}} \pm 0$ \\
\hline $\begin{array}{l}\text { Concentration of total phenolics } \\
\left(\mathrm{mg} \text { of gallic acid. } 100 \mathrm{~g}^{-1}\right)\end{array}$ & $86.6^{\mathrm{a}} \pm 2.8$ & $85.6^{\mathrm{a}} \pm 1.4$ & $84.3^{a} \pm 2.9$ & $77.3^{\mathrm{a}} \pm 2.1$ & $81.1^{\mathrm{a}} \pm 4.6$ & $84.8^{\mathrm{a}} \pm 0.7$ & $81.4^{\mathrm{a}} \pm 1.6$ \\
\hline
\end{tabular}

Identical letters in the same line do not differ significantly $(\mathrm{p}>0.05)$ among themselves. Means of three assays. 


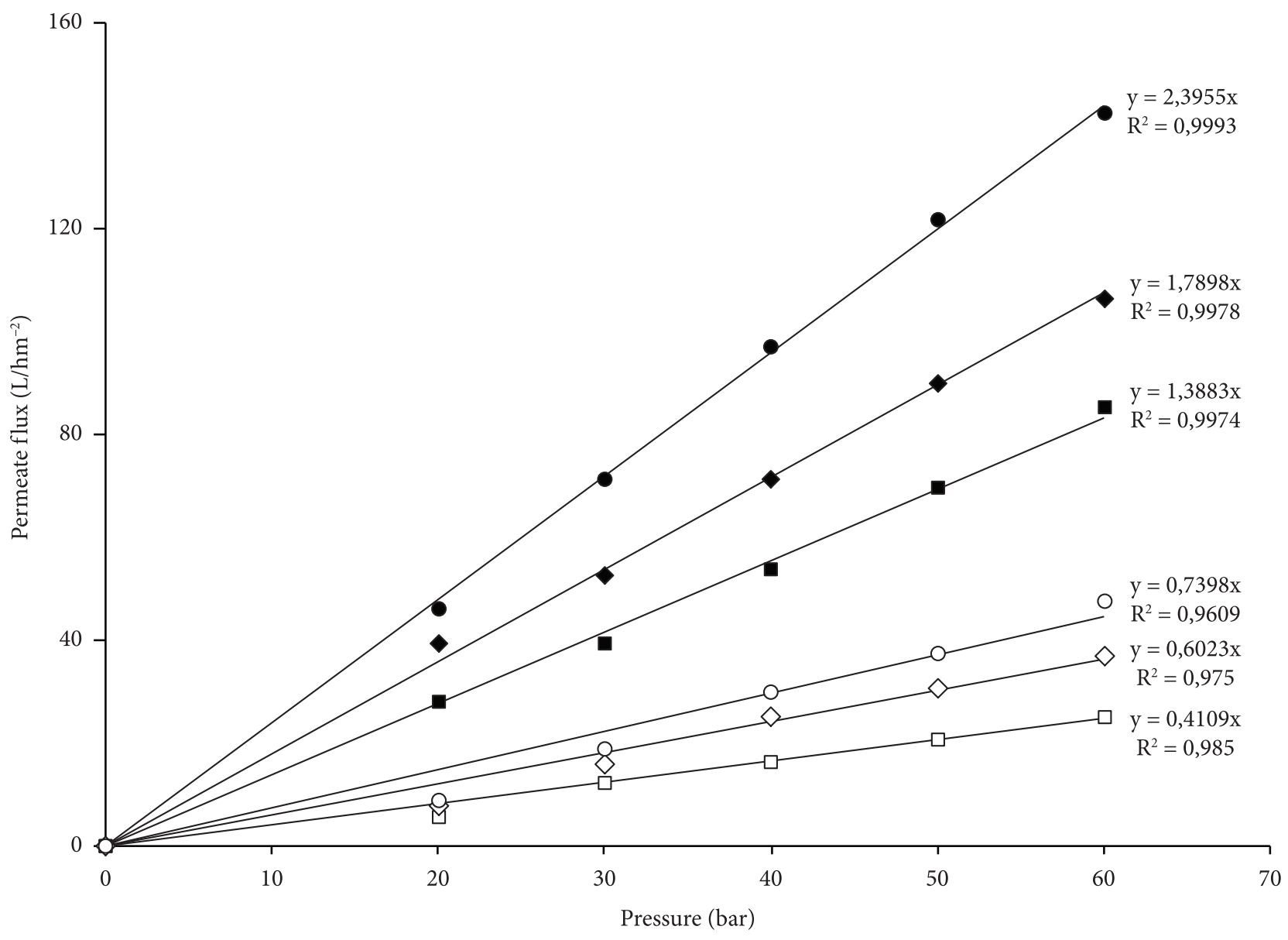

- Water $20^{\circ} \mathrm{C} \bullet$ Water $30^{\circ} \mathrm{C} \diamond$ Water $40^{\circ} \mathrm{C} \square$ Juice $20^{\circ} \mathrm{C} \diamond$ Juice $30^{\circ} \mathrm{C} \bigcirc$ Juice $40{ }^{\circ} \mathrm{C}$

Figure 1. Permeate flux of the membrane to water and to the centrifuged pineapple juice.

increase in concentration of total solids that increases the osmotic pressure, and the juice viscosity (Figure 3 ). This latter is a direct consequence of the concentration of solids along the process (SÁ; CABRAL; MATTA, 2003).

The maximum value of concentration reached in the reverse osmosis process was limited by the osmotic pressure and by the viscosity of the product, as well by the polarization of the concentration.

The osmotic pressure of fruit juices increased with the increasing in the concentration of sugars (100 and 200 bar for juices at 42 and $60^{\circ} \mathrm{Brix}$, respectively). These values influenced the reverse osmosis concentration process and, because of that, the concentration of the product was not higher than $20 \%$. Moreover, the process is not convenient from the economical point of view, and due to these limitations, it can be considered an advantageous technique as a pre-concentration step (CASSANO et al., 2003).

Specifically, pineapple juice with $14 \%$ of total solids exhibits an osmotic pressure of approximately 20 bar (GIRARD; FUKUMOTO, 2000). The soluble solids content was determined during the process time (Figure 3).

The volumetric reduction factor, defined as the relationship between the volume of initial feed (centrifuged juice) and the

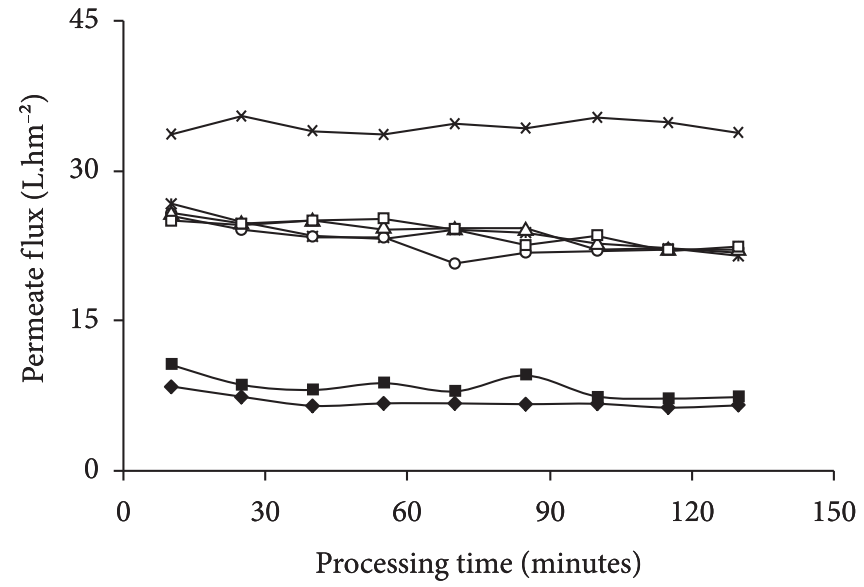

$\rightarrow 20$ bar $-20^{\circ} \mathrm{C} \rightarrow 20$ bar $-40^{\circ} \mathrm{C} \rightarrow 60$ bar $-20^{\circ} \mathrm{C}$
$\rightarrow 60$ bar $-40^{\circ} \mathrm{C}-40$ bar $-30^{\circ} \mathrm{C} \rightarrow 40$ bar $-30^{\circ} \mathrm{C}$
$\rightarrow-40$ bar $-30^{\circ} \mathrm{C}$

Figure 2. Permeate flux according to pressure and temperature in the stationary stage.

volume of the fraction retained by the membrane (concentrated juice), was 2.9, which corresponds to the soluble solids content of $31.2^{\circ}$ Brix. 
Table 2. Physicochemical characteristics and instrumental color parameters of pineapple juice. Samples of the Whole Juice (WJ), Centrifuged Juice (CJ), and Concentrated Juice (COJ) by reverse osmosis.

\begin{tabular}{lccc}
\hline & WJ & CJ & COJ \\
\hline $\mathrm{pH}$ & $3.45 \pm 0,01$ & $3.48 \pm 0,01$ & $3.36 \pm 0,01$ \\
Acidity (mg.100 g ${ }^{-1}$ Citric acid) & $0.69^{\mathrm{a}} \pm 0$ & $0.67^{\mathrm{b}} \pm 0,05$ & $1.94 \pm 0,05$ \\
Soluble solids ( ${ }^{\circ}$ Brix) & $10.9^{\mathrm{a}} \pm 0,1$ & $10.6^{\mathrm{a}} \pm 0,4$ & $31.2 \pm 0,6$ \\
Total solids (g.100 $\mathrm{g}^{-1}$ ) & $11.1^{\mathrm{a}} \pm 0,02$ & $10.9^{\mathrm{a}} \pm 0,56$ & $32.5 \pm 0,5$ \\
Concentration of phenolics (mg of Gallic acid Eq.100 g-1) & $89.1^{\mathrm{a}} \pm 0,1$ & $91.1^{\mathrm{a}} \pm 2,6$ & $242.4 \pm 11,1$ \\
$\mathrm{~L}^{*}$ & $22.7^{\mathrm{b}} \pm 0,09$ & $40^{\mathrm{a}} \pm 7,7$ & $25.1 \pm 2,7$ \\
$\mathrm{a}^{*}$ & $-3.5^{\mathrm{a}} \pm 0,05$ & $-0.9^{\mathrm{b}} \pm 0,3$ & $-0.7 \pm 0,5$ \\
$\mathrm{~b}^{*}$ & $10.4^{\mathrm{b}} \pm 0,2$ & $16.3^{\mathrm{a}} \pm 1,5$ & $13.1 \pm 1,7$ \\
Haze $^{*}$ & $95.8^{\mathrm{a}} \pm 0,2$ & $83.8^{\mathrm{b}} \pm 5,2$ & $94.6 \pm 2,2$ \\
\hline
\end{tabular}

L: $(0=$ black and $100=$ white $)$ a $)(-80$ up to zero $=$ green and from zero to $+100=$ red $) ; b)(-100$ up to zero $=$ blue, from zero up to $+70=$ yellow $)$. Means of the two processes and means

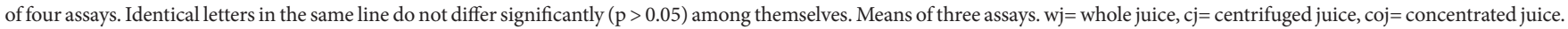

Sá, Cabral and Matta (2003) concentrated clarified pineapple juice by reverse osmosis at 60 bar and $25{ }^{\circ} \mathrm{C}$ obtaining a concentration factor of 4.5 with a soluble solids content of $30.7^{\circ}$ Brix. However, it must be pointed out that the juice was previously clarified by an enzymatic treatment and microfiltration that resulted in a juice without suspended solids, which does not occur when the juice is only centrifuged.

The results of the analyses of the pineapple juice during the different steps of the process are shown in Table 2.

There was a 2.9 fold increase in the parameters of total soluble solids, total solids, and total acidity, and this increase is proportional to the concentration factor obtained during the process. With regard to the content of phenolic composites, there was a 2.6 fold increase, possibly as a consequence of the oxidation along the process. This loss may be avoided industrially using an inert gas such as nitrogen, which would avoid the oxidation of the composites or by using chicanes, which would prevent the formation of vortices in the feed tank.

There was a decrease in the luminosity of the concentrated juice regarding the centrifuged juice and consequently an increase in haze. Concerning the color 'a' parameter, the juices within the range that characterizes the color green, and the feed (centrifuged juice) and the concentrated juices presented the same intensity of this color. Color 'b' parameter presented values within the range of the color yellow for the single strength and concentrated juices, and the single strength juice presented the highest intensity of this color.

The results of the mineral analyses are shown in Table 3. Regarding the human dietary daily intake, the results obtained for the contents of magnesium, phosphorous, potassium, and calcium in the concentrated juice presented a threefold increase. The contents of iron and copper presented a fourfold increase and those of manganese and zinc presented a five fold increase. It must be pointed out that the content of minerals of the concentrated juice was similar and even higher to the volumetric concentration factor of the process.

The result of the preference test and purchase intention of the concentrated juice by reverse osmosis and the three commercial brands of the concentrated pineapple juice is presented in Table 4.
Table 3. Mineral analyses of the centrifuged and concentrated pineapple juices.

\begin{tabular}{ccc}
\hline Compound $\left(\mathbf{g} .100 \mathbf{~ g}^{-1}\right)$ & Centrifuged & Concentrated juice \\
\hline Magnesium & $8.5 \pm 0.22$ & $25.4 \pm 0.79$ \\
Phosphorous & $6.2 \pm 0.1$ & $19.2 \pm 1.5$ \\
Potassium & $92.9 \pm 2.5$ & $281.3 \pm 11.1$ \\
Calcium & $8.7 \pm 0.3$ & $27.1 \pm 1.2$ \\
Manganese & $0.1 \pm 0$ & $0.5 \pm 0$ \\
Iron & $0.1 \pm 0$ & $0.4 \pm 0$ \\
Copper & $0.1 \pm 0$ & $0.4 \pm 0.1$ \\
Zinc & $0.1 \pm 0$ & $0.5 \pm 0$ \\
\hline
\end{tabular}

Means of three assays

Table 4. Consumer preference results ${ }^{\star}$ and consumer purchase intention ${ }^{\star \star}$ results.

\begin{tabular}{lcc}
\hline Sample & Preference test $^{*}$ & Purchase intention $^{\star *}$ \\
\hline Concentrated by & $5.7^{\mathrm{a}} \pm 2,3$ & $5.5^{\mathrm{a}} \pm 2,0$ \\
reverse osmosis & & \\
Commercial 1 & $4.6^{\mathrm{bc}} \pm 2,5$ & $4.4^{\mathrm{bc}} \pm 2,1$ \\
Commercial 2 & $4.9^{\mathrm{b}} \pm 2,5$ & $4.6^{\mathrm{b}} \pm 2,1$ \\
Commercial 3 & $4.0^{\mathrm{c}} \pm 2,2$ & $4.2^{\mathrm{c}} \pm 1,9$ \\
\hline
\end{tabular}

Identical letters in the same line do not differ significantly $(p>0.05)$ among themselves. *Assessed in a 9-point structured hedonic scale varying from 1: "I extremely disliked it" to 9: "I extremely liked it". ${ }^{* \star}$ Assessed in a structured scale varying from 1: "I would not definitely buy it" to 7: "I would definitely buy it".

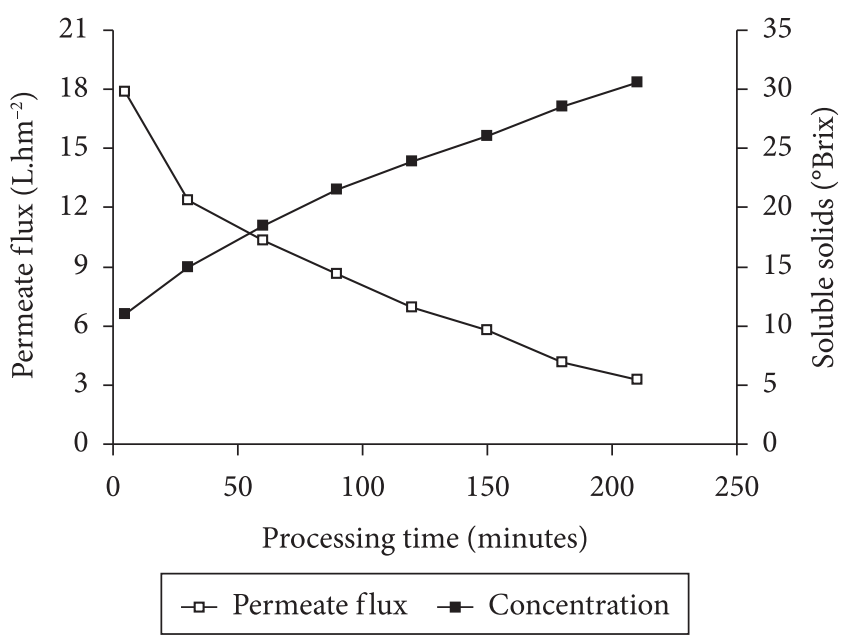

Figure 3. Permeate flux and concentration of soluble solids of pineapple juice in plate and frame module of reverse osmosis. Means of three assays. 
In the preference test, the concentrated juice by reverse osmosis obtained the highest mean (5.7) when compared with the commercial samples 1, 2, and 3 (means 4.6, 4.9 and 4.0, respectively). Through the analysis of the variance (ANOVA) and Fisher, it was verified that the difference between the concentrate juice by reverse osmosis and the commercial brands was significant $(\mathrm{p}<0.05)$.

The consumer purchase intention and the consumer preference presented the same tendency with a mean of 4.5 for the concentrated juice by reverse osmosis and 3.4, 3.6, and 3.2 for the commercial samples 1,2, and 3, respectively.

Again, the purchase intention for the concentrated juice by reverse osmosis was higher than the commercial ones $(\mathrm{p}<0.05)$.

\section{Conclusions}

The reverse osmosis process was effective in the preconcentration of the pineapple juice resulting in a juice with a soluble solids content of $31^{\circ} \mathrm{Brix}$ when processed at $60 \mathrm{bar}$ and $20^{\circ} \mathrm{C}$.

The 60 bar and $20{ }^{\circ} \mathrm{C}$ were the consumers' preferred conditions and were utilized for the concentration process of the pineapple centrifuged juice.

It was observed that the juice concentrated by reverse osmosis was chosen as favourite by consumers when compared to the brands of commercial pineapple juice. This result suggests that the reverse osmosis process was able to maintain its sensory characteristics in relation to the juice used as a feed showing that, like conventional concentration processes, the reverse osmosis did not affect the compounds responsible for the sensory characteristics.

\section{References}

ÁLVAREZ, S. et al. A new integrated membrane process for producing clarified apple juice and apple juice aroma concentrate. Journal of Food Engineering, v. 46, p. 109-125, 2000. http://dx.doi. org/10.1016/S0308-8146(00)00139-4

ASSOCIATION OF OFICIAL ANALYTICAL CHEMISTS - AOAC. Official methods of analysis. 18. ed. Gaithersburg: AOAC, 2005.

BARTOlOMÉ, A. P.; RUPÉREZ, P.; FÚSTER, C. Pineapple fruit: morphological characteristics, chemical composition and sensory analysis of red spanish and smooth cayenne cultivars. Food
Chemistry, v. 53, p. 75-79, 1995. http://dx.doi.org/10.1016/03088146(95)95790-D

CABRAL, L. M. C.; FREIRE JUNIOR, M.; MATTA, V. M. Suco de abacaxi Tecnologia de bebidas: matéria prima, processamento, bpf/appcc, Legislação e Mercado. São Paulo: Ed. Edgard Blucher, 2005. p. 205-220.

CASSANO, A. et al. Clarification and concentration of citrus and carrot juices by integrated membrane processes. Journal of Food Engineering, v. 57, p. 153-163, 2003. http://dx.doi.org/10.1016/ S0260-8774(02)00293-5

DELIZA, R. The use of "ideal point" scale to determine the best sugar and dilution levels of passion fruit juice by consumers. Alimentaria, v. 38 , n. 24 , p. 109-113, 2001.

FELLOWS, P. J. Tecnologia do processamento de alimentos-princípio e prática. 2. ed. São Paulo: Artmed, 2006. cap. 13, p. 289-304.

GIRARD, B.; FUKUMOTO, L. R. Membrane processing of fruit juice and beverages: a review. Critical Reviews in Food Science, v. 40, n. 2, p. 91-157, 2000. PMid:10770272. http://dx.doi. org/10.1080/10408690091189293

HOLLMAN, P. C. H.; HERTOG, M. G. L.; KATAN, M. B. Analysis and health effects of flavonoids. Food Chemistry, v. 57, p. 43-46, 1996. http://dx.doi.org/10.1016/0308-8146(96)00065-9

JESUS, D. F. et al. Orange (citrus sinensis) juice concentration by reverse osmosis. Journal of Food Engineering, v. 81, p. 287-291, 2007. http://dx.doi.org/10.1016/j.jfoodeng.2006.06.014

JOSHIPURA, K. J. et al. Fruit and vegetable intake in relation to risk of ischemic stroke. Journal of American Medical Association, v. 282, p. 1233-1239, 1999. http://dx.doi.org/10.1001/jama.282.13.1233

MACFIE, H. J. et al. Designs to balance the effect of order of presentation and first-order carry-over effects in hall tests. Journal of Sensory Studies, v. 4, p. 129-148, 1989. http://dx.doi.org/10.1111/j.1745459X.1989.tb00463.x

MEILGAARD, M.; CIVILLE, G. V.; CARR, B. T. Sensory evaluation techniques. 2. ed. New York: CRC Press, 1991.

MULDER, M. Basic principles of membrane technology. Kluwer Academic Publishers, 1991.

SÁ, I. S.; CABRAL, L. M. C.; MATTA, V. M. Concentração de suco de abacaxi através dos processos com membranas. Brazilian Journal of Food Technology, v. 6, p. 53-62, 2003.

SINGLETON, V. L.; ROSSI, J. A. Colorimetry of total phenolics with phosphomolybdic - phosphotungstic acid reagents. American journal of enology viticulture, v. 20, p. 144-158, 1965.

VINSON, J. A. et al. Phenol antioxidant quantity and quality in foods: fruits. Journal of Agriculture Food Chemistry, v. 49, p. 53155321, 2001. PMid:11714322. http://dx.doi.org/10.1021/jf0009293

XLSTAT. XLSTAT 7.5 software. version 2007.4. XLSTAT, 1995. 